\title{
EFL Students' Pronunciation Problems in Presenting Thesis Proposal at Tertiary Level of English Department
}

\author{
Arif Rahman $^{1 *}$, Lalu Nawasier Tralala ${ }^{2}$ \\ 1*Master Program in English Language Education UNDIKMA \\ ${ }^{2}$ ASITA NTB \\ *Corresponding Author. Email: arifrahman058020@gmail.com
}

\begin{abstract}
The aim of the research is to investigate EFL Students' Pronunciation Problems in Presenting Thesis Proposal at Tertiary Level of English Department. This qualitative study reported in this article focused on segmental features problems. The instruments used to collect the data needed in this study were the researcher, recording, and Dictionary. The data analysis covered consonant and vowel pronunciation problems. was based on the theories of phonetics proposed by George Yule and Jacobs, which embraces voicing, manner of articulation and place of articulation for English consonant production and the tongue part and position, sound length, and mouth forming for English vowel production. The result of the study shows that the research subject encountered a number of segmental pronunciation problems consisting of consonants and vowels including pure vowels and diphthongs. Furthermore, this research revealed that the problem with consonant sounds were the substitution of the sounds $[\mathrm{v}],[ð],[\theta],[\mathrm{t}],[],[][\mathrm{z}]$ and the deletion of the sounds $[\mathrm{k}],[],[\mathrm{t}]$, and $[\mathrm{s}]$. The problem with pure vowel sounds were the

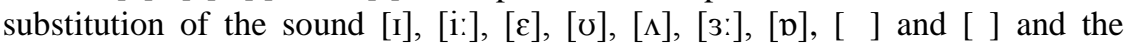
insertion of the sound [ ] between two consonant sounds. The problem with diphthongs were: the monophthongization of the sound [a] , [av], [er], [ı]], [əv], and the replacement of the sounds [eI] and [Iә] with other diphthongs. It is suggested for the next researchers to investigate pronunciation problems related to supra-segmental aspects and phonemic opposition. and factors driving pronunciation problems in the EFL Classroom setting.
\end{abstract}

Article History

Received: 29-05-2021

Revised: 25-07-2021

Accepted: 25-08-2021

Published: 07-09-2021

Key Words:

Pronunciation

Problem, Phonology,

Phonetic, Segmental

Feature.

How to Cite: Rahman, A., \& Tralala, L. (2021). EFL Students' Pronunciation Problems in Presenting Thesis Proposal at Tertiary Level of English Department. Jurnal Kependidikan: Jurnal Hasil Penelitian dan Kajian Kepustakaan di Bidang Pendidikan, Pengajaran dan Pembelajaran, 7(3), 576-588. doi:https://doi.org/10.33394/jk.v7i3.3921

https://doi.org/10.33394/jk.v7i3.3921

This is an open-access article under the CC-BY-SA License.

\section{Introduction}

Pronunciation plays an important part in improving an English speaking skill, It is inline with Ellis as cited in Sahatsathatsana (2017) points out that good pronunciation is a key to have good speaking. In communication process, good pronunciation can avoid verbal misunderstanding speakers need to deliver their speech with proper English pronunciation in order that the message clearly delivered and understandable. At the same line, Gilakjani (2011) says that people who had incorrect pronunciation would not be successful in communication. However, learning pronunciation is quite difficult for Indonesian students since they have been used to speaking their mother tongue. Due to the English is greatly different from Indonesian language in its pronunciation system. The common problem of learning English pronunciation is caused by the differences between the sound systems of the two languages. There are some sounds in English which do not exist in Indonesian. The vowels, such as [æ], [I:], [u:] and consonants, such as [ð], [Ө], [ ], do not exist in Indonesian. It will be difficult for Indonesian students to pronounce them. Pronunciation, defined by the Oxford English Dictionary, refers someone's competence in producing sound used to deliver 
meanings. Then, the study to find out pronunciation problems becomes necessary since it is one of the problems in speaking practice. Someone with inaccurate pronunciations might jumble sounds. Sound or combination of sounds are causing different meanings, it will, thus, lead the hearers to misunderstand what is being tried to deliver. For instance, the word leave contains the sounds [1], [i ] and [v]. When the sound [i ] is pronounced [I] that finally results in /liv/, the meaning is changed because /liv/ will be interpreted as the word live. Then, the hearers will misunderstand the speech because the speaker is unintentionally misleading the speech by performing mispronunciation (Alimemaj, 2014).

The problem of pronunciation needs investigating in the English Department of UNDIKMA, in which the majority of the students are those who speak Indonesian as a first or second language, to discover the problematic English sounds encountered by the tertiary students. This was due to the assumption that mispronunciations were still frequently performed by the tertiary students of the English Department in their speaking practices. Although they had been in the tertiary level of speaking courses, they were still identified to perform mispronunciations. This research then tried to identify the often mispronounced English sounds by the EFL learners of the English Department UNDIKMA. This will help Learners who are teaching or and studying English pronunciation as the English sounds often mispronounced have already been identified so that they will be more aware of those mispronunciations. In the English Department learners start studying to speak skill ever since they are in the first semester to sixth semester with Public Speaking Course. After completing the whole courses, the students are required to have the last final project in form of thesis proposal. These thesis proposals need to present it through English speaking in the seminar. Thus, the discovery of this study would be the English sounds, vowels, and diphthongs, which were very problematic since they were performed by those who had trained for English speaking through those courses.

Studies in this field have been conducted several times in Indonesia. For instances, Alimemaj (2014) has investigated the English phonological problems encountered by Albanian learners. The second, Malah and Rashid (2015) analyzed the contrast of the segmental phonemes between English and Hausa Language. Then, a research on such fields also needs conducting among Indonesia learners to investigate what pronunciation problems encountered by Indonesian learners. Rosyidah (2014) examined the pronunciation problems in Language Morning Program held in Islamic Boarding School. Andi-Pallawa (2013) also investigated pronunciation problems encountered by Indonesian learners embracing a comparative analysis between both languages. However, the subjects of their researches were those who were mostly not demanded to have a good mastery in English speaking that they were not encouraged to have a good English pronunciation. Thus, every single sound of English would tend to be problematic. Then, this study aimed to discover serious problematic English sounds, vowels, and diphthongs, seeing from their pronunciations in presenting thesis proposal (Szynalski, 2020).

\section{Research Method}

This research applied qualitative approach and interpretative study as a research design. Ary et al (2010) says a qualitative approach is the way for understanding behaviour meaning or action meaning by human in particular social setting. Ary et al (2010) also point out that interpretative study is a study to describe phenomenon that appeared in humans' experience which is occurred naturally. This study was designed to investigate pronunciation problems of English sounds, consisting of consonants, vowels, and diphthongs performed by the English Department students in the presentation of the thesis proposal. The instruments 
used to collect the data needed in this study were the researcher, recording, and Dictionary. The researcher came to the presentation of the thesis proposal in which the subjects of the research were performing their English speaking practices. Then, the researcher analyzed the results qualitatively with three steps by Miles, Huberman and Saldana (2014), i.e., 1) Recording: the data-collecting process in this research was done by recording the speaking practices performed by the English Department students during the presentation of the thesis proposal. The recordings were then listened to catch and write down the transcription, 2) Dictionary: the Oxford Tertiary Learners' Dictionary was used as a determinant to do the analysis since it was the commonly used dictionary among the English Department students.

The data of this research were the speaking practices performed by the English Department students in the presentation of the thesis proposal. The researcher recorded students' thesis proposal presentation during thesis proposal seminar in March to April 2021. Totally, ten students' thesis proposal presentations were taken as the data source. This research took and recorded the data directly during the presentation of the thesis proposal. Some steps were done by the researcher to collect the data. The first step was directly coming to the class to observe and listen to the presentation of the thesis proposal. While observing and listening, the students' performances were recorded. The second step was listening to the recording and then writing down the transcription and marking every single English sound which was mispronounced. The last step was noting and classifying the data based on their segmental phonological characteristics (Miles, Huberman and Saldana, 2014).

The data analysis of the research covered two stages; The first stage was grouping the mispronounced English sounds. The whole collected data which have been written down are firstly classified or grouped based on their segmental phonological characteristic. Second, the data were allocated into two main classifications; consonant and vowel pronunciation problems. The vowel pronunciation problem is divided into three branches; pure vowels, diphthong and trip thong while the consonant pronunciation problem does not have any branch to divide. The second stage was analyzing how the mispronounced sounds were becoming the pronunciation problems. It began with analyzing the segmental features of the mispronounced English phonemes which had been classified. To check off the accuracy of the analysis, The Oxford Tertiary Learners' Dictionary and the theory of English phonetics and phonology proposed by Yule (2010) and Roach (2009) were used as the determinants to convey the accuracy of the analysis. The phonological environments of some mispronounced English sounds were explained as it was considered necessary.

\section{Finding and Discussion}

To answer the research question, the finding presents the analysis of the research data by categorizing the data into two classes; consonant and vowel including diphthong, and explaining the segmental features which become the pronunciation problems occupied by the ten research subjects during the presentation of their thesis proposals.

\section{1) The problem with the English Consonants}

This research identified that there are the consonant sounds which were inaccurately pronounced by the subjects of the research in their presentation of their thesis proposal. The accuracy was determined with the phonetic transcription provided on the Phonetic Latin alphabet standardized by (International Phonetic Association, and the Oxford Tertiary Learner's Dictionary, 2015). The inaccurate production of the consonants will be described through the phonetic theories of consonants proposed by Roach (2009) and Yule (2010) which focus on the voicing, the manner of articulation and the place of articulation. 
a). The Sound [v].

The following table shows some of the words with the sound [v] which was substituted with the sound [f] by the research subjects.

Table 1. Problem with the Sound [f]

\begin{tabular}{|c|c|c|c|}
\hline Position & Word & $\begin{array}{l}\text { The correct } \\
\text { Pronunciation }\end{array}$ & $\begin{array}{l}\text { The subject } \\
\text { pronunciation }\end{array}$ \\
\hline Initial & $\begin{array}{l}\text { View } \\
\text { Very }\end{array}$ & $\begin{array}{l}\text { /vju / } \\
/ \text { / ri// }\end{array}$ & $\begin{array}{l}\text { /fju / } \\
\text { / f ri/ }\end{array}$ \\
\hline Medial & $\begin{array}{l}\text { Investigate } \\
\text { Seven } \\
\text { Divide } \\
\text { Level } \\
\text { Convey }\end{array}$ & $\begin{array}{l}\text { /In'vestigeit/ } \\
\text { / s v( )n/ } \\
\text { /di'vaid/ } \\
\text { / l v( )1/ } \\
\text { /kən'vei/ }\end{array}$ & $\begin{array}{l}\text { /In' festigeit/ } \\
\text { / s f n/ } \\
\text { /di' faid/ } \\
\text { / l f l/ } \\
\text { /kən' fei/ }\end{array}$ \\
\hline Final & $\begin{array}{l}\text { Of Five } \\
\text { Solve }\end{array}$ & $\begin{array}{l}\text { / v/, /( )v/ } \\
/ \text { farv/ } \\
/ \mathrm{s} \mathrm{lv} /\end{array}$ & $\begin{array}{l}\text { / f/ } \\
\text { /farf/ } \\
\text { /s lf/ }\end{array}$ \\
\hline
\end{tabular}

The English consonant sound [v] is described as a voiced, labiodentals and fricative sound which means that its production should fulfill those three main features of [v] sound. The problem encountered by the research subjects in accordance with the sound [v] was the voicing while they dealt with the manner and place of articulation correctly. Some of them devoiced the sound [v] that eventually resulted in the production of the sound [f]. This is because the sound $[\mathrm{v}]$ and [f] have the same manner and place of articulation, but the sound [f] is voiceless which the sound [v] is voiced. In simplicity, the research subjects substituted the sound [v] with the sound [f].

Finally, this kind of substitution in the final position, for example, happened in the words "five" /farv/ and "solve" /splv/. The substitution of the final[v] sound made pronounced /farf/ and /splf/. The change of the sound [v] into [f] in the final position performed by the subjects happens under three different phonological environments. First, it is preceded by a vowel. For instance, in the subject pronunciation of the word "of" as / f/, the sound [f] is preceded by the vowel [ ]. Second, it is preceded by a diphthong. For instance, in the subject pronunciation of the word "five" as /farf/, the sound [f] is preceded by the diphthong [ar]. Third, it is preceded by a consonant. For instance, in the subject pronunciation of the word "solve" as /s lf/, the sound [f] is preceded by the consonant [1].

b). The Sound[ð]

The following table shows the sound [ð] which was substituted with sound[d] or [ $\theta]$ by the subject.

Table 2. Problem with the Sound [ð]

\begin{tabular}{llll}
\hline Position & Word & $\begin{array}{l}\text { The correct } \\
\text { pronunciation }\end{array}$ & $\begin{array}{l}\text { The subject } \\
\text { pronunciation }\end{array}$ \\
\hline Initial & $\begin{array}{l}\text { The } \\
\text { Then }\end{array}$ & $/ ð / / / \mathrm{I} / / / \mathrm{\partial i} /$ & $/ \mathrm{d} /$ \\
& $/ ð \mathrm{en} /$ & $/ \mathrm{den} /$ \\
\hline Final & With & $/ \mathrm{wI} /$ & $/ \mathrm{wI} \theta /$ \\
\hline
\end{tabular}

The English consonant sound [ð] is described as a voiced dental fricative sound that its production should fulfill those three main features of [ð] sound. The problem encountered by the research subjects regarding of the sound [ð] arose in two position; initial and final. In the case of the sound [ð] in the initial position, the research subjects articulated the /ð/ in the improper way of the manner and the place of articulations while the voicing remained correct. One subject did not touch his tongue to the dental area, but to the nearest place of 
articulation which was the alveolar ridge and changed its manner of articulation to be a stop or plosive. Thus, this eventually result edit the production of the sound [d] which substituted the sound [ð].

This kind of substitution happened, for example, in the words the /ð /and "then" /ðen/. The substitution of the initial [ð] with the sound [d] by the research subjects made them pronounced /d/ and /den/. This initial substitution occur under one phonological environment. The change of the [ð] in the initial position is always followed a vowel. For instance, in the subject pronunciation of the word, "then" as /ðen/, it can be identified that the sound [d] is followed by the sound [e] which is a vowel.

\section{c). The Sound $[\theta]$.}

The following table shows the sound $[\theta]$ which was substituted with sound [t] by the subject occurring in the initial and final position and the substitution of the sound $[\theta]$ with [s] in the initial position committed by the subjects.

\begin{tabular}{llll} 
Position & Word & $\begin{array}{c}\text { Table 3. problem with the sound }[\theta] \\
\text { The } \\
\text { pronunciation } \\
\text { correct }\end{array}$ \\
\hline Initial & The subject pronunciation \\
& Three & $/ \theta$ ank/ & $/ \mathrm{tank} /$ \\
& Third & $/ \theta \mathrm{ri} /$ & $/ \mathrm{tri} /$ \\
Medial & Method & $/ \mathrm{m} \theta \mathrm{d} /$ & $/ \mathrm{s} \mathrm{rd} /$ \\
\hline
\end{tabular}

Phonetically, the sound [ $\theta]$ is described as a voiceless dental fricative sound. Those three phonetic aspects should be occupied when producing the sound $[\theta]$. However, some of the subject in some cases did not meet two of the three phonetic aspects when they articulated the sound $[\theta]$. They changed the place of articulation of the sound $[\theta]$ from dental to alveolar. In accordance with the manner of articulation, the sound [ $\theta]$ that should actually be articulated through producing an air stream as it is fricative was articulated with the manner of stop or plosive. The voicing of this sound was produced correctly. Those two changes of the phonetic aspects of the sound $[\theta]$ resulted in the production of the sound $[t]$ that substituted the sound $[\theta]$. This kind of substitution occurred in two position; initial and medial.

In this cases, the subject articulated sound $[\theta]$ is in the proper way of voicing and manner of articulation. The sound [ $\theta]$ was voicelessly articulated with a fricative manner. However, the place of articulation of the sound $[\theta]$ was changed by the subject from dental to alveolar. This eventually ended up with the production of the sound [s] which is phonetically described by a voiceless alveolar fricative sound. It means that the sound $[\theta]$ was substituted with the sound [s] by the research subjects. This kind of substitution happened only once and it was in the initial position. It happened to the word ,third $/ \theta(\mathrm{r}) \mathrm{d} /$. The medial $[\theta]$ sound was substituted with the sound [s] that made it pronounced $/ \mathrm{s} \mathrm{rd} /$. The change of the initial sound $[\theta]$ to the sound [s] performed by the subject occurs in one phonological environment. The change of the sound $[\theta]$ to the sound $[\mathrm{s}]$ in the initial position is followed by a vowel. For instance, in the subject pronunciation of the word ,third ${ }^{\mathrm{ee}}$ as /sa:rd/, it can be identified that the sound [s] is followed by the long vowel [ ].

d). The Sound [t $]$

The following table shows the sound [t] which was replaced with sound [c] by the subject occurring in the medial position. This problem did not happen in the initial and final position. 
Table 4. Problem with the Sound [ $t]$

\begin{tabular}{|c|c|c|c|}
\hline Position & Word & $\begin{array}{l}\text { The c } \\
\text { pronunciation }\end{array}$ & correct The subject pronunciation \\
\hline Medial & $\begin{array}{l}\text { Feature } \\
\text { Switching }\end{array}$ & $\begin{array}{l}/ \text { fi t }(\mathrm{r}) / \\
/ \text { swit } \int \mathrm{in} /\end{array}$ & $\begin{array}{l}\text { / fi c r/ } \\
/ \text { swicry/ }\end{array}$ \\
\hline
\end{tabular}

The sound [t] can be phonetically described as a voiceless palatal affricative sound. The articulation of the sound [t $\int$ should be done through those three phonetic aspects. The problem with the sound [t $]$ encountered by the research subjects was regarding of the manner of articulation. The affricative [t $\int$ which should actually be articulated based on the manner of articulation, by briefly stopping the air stream and immediately producing a sudden release of the stopped air stream to create a fraction was articulated without producing the friction while the voicing and the place of articulation remained unchanged. This, thus, resulted in the production of the sound [c] since the sound [t $]$ and [c] have two phonetic aspects in common which are the manner and the place of articulation while they differ only in the aspect of manner of articulation by means the sound $[\mathrm{t}]$ is affricative and the sound [c] is stop or plosive. This kind of substitution happened only in the medial position. For instance, the medial [ $\mathrm{t}]$ sound was substituted with the sound [c] by the research subjects in the word "feature" / fi t (r)/ and „switchinge /swit $\int \mathrm{ry} /$. The substitution of the medial $\left[\mathrm{t} \int\right.$ with the sound [c] made those words pronounced / fi c (r)/ and $/$ swicin/.

It can be seen from the table that the change of the medial sound [t ] to the sound [c] performed by the subject happens under two different phonological environments. First, the change of the sound [ $\mathrm{t}]$ to the sound [c] in the medial position is preceded and followed by a vowel. For instance, in the subject pronunciation of the word „feature ee as /'fi:crr/, it can be identified that the sound [c] is preceded by the vowel [i] and followed by the vowel [ ]. Second, the change of the sound [t ] to the sound [c] in the medial position is preceded by a consonant and followed by a vowel. For instance, in the subject pronunciation of the word "switching" as /switcrin/, it can be identified that the sound [c] is preceded by the consonant [t] and followed by the vowel [I].

e). The Sound [ ]

The following table shows the sound [ ] which was replaced with sound [ ] by the subject occurring only in the medial position during the research.

Table 5. Problem with the Sound [ ]

\begin{tabular}{|c|c|c|c|}
\hline Position & Word & $\begin{array}{l}\text { The } \\
\text { pronunciation }\end{array}$ & correct The subject pronunciation \\
\hline Medial & $\begin{array}{l}\text { Conclusion } \\
\text { Cohesion }\end{array}$ & $\begin{array}{l}\text { /k n klu ( )n / } \\
/ \mathrm{k} \text { hi ( )n / }\end{array}$ & $\begin{array}{llll}/ \mathrm{k} & \mathrm{n} \mathrm{klu} & \mathrm{n} / \\
/ \mathrm{k} & \mathrm{h} & \mathrm{n} /\end{array}$ \\
\hline
\end{tabular}

The sound [ ] is a consonant sound that should be articulated through three phonetic aspects: voiced, palatal and fricative. Those three aspects should be completely fulfilled all together in order to produce the proper sound [ ]. Otherwise, the sound [ ] will be mistakenly altered into another sound. The problem encountered by the research subjects related to the sound [ ] was in the voicing aspect. They devoiced sound [ ] that resulted in the production of a voiceless, palatal and fricative sound. This sound can be addressed by the sound [ ] which substituted the sound [ ]. This kind of substitution happened only in one position; medial position. It happened to the word ,,conclusion" $/ \mathrm{k} \mathrm{n} \mathrm{klu} \mathrm{(} \mathrm{)n} \mathrm{/} \mathrm{and} \mathrm{,,cohesion"} / \mathrm{k}$ hi ( )n /. The substitution of the medial [ ] sound with the sound [ ] made those words pronounced $/ \mathrm{k} \mathrm{n}$ klu $\mathrm{n} /$ and $/ \mathrm{k} h \mathrm{~h} /$. It can be seen that some vowel changes also happened and they will be discussed in the vowel section. 


\section{2). The Problem with the English Vowels and Diphthongs}

The findings of the study shows that there are same vowel sounds which were inaccurately pronounced by EFL learners during presentation of thesis proposal. This is in line with Purba et al (2019) who said that these problems were occurred because the students didn't have the material about phonetic symbols yet. They still confused how to pronounce English short vowel sounds in English words correctly. The accuracy was determined with the phonetic transcription provided on the Latin alphabet standardized by the (International Phonetic Association, 2015) and the Oxford Advanced Learner's Dictionary. The inaccurate production of the consonants will be described through the phonetic theories of vowels proposed Yule (2010) which focus on the part and the position of the tongue. In addition, it is important to note that the phonological environment of the vowel substitution will not be described in each vowel as there must always be only one possible phonological environment; an initial vowel must always be followed by a consonant, a medial vowel must always be preceded and followed by consonants, and a final vowel must always be preceded by a consonant.

\section{a) The Vowel [I]}

The sound [I] is produced in the close front area. This means that when the sound [I] is produced, the front part of the tongue is heightened to the roof of the mouth with the lips are slightly spread. However, the front part of the tongue is not heightened as high as possible to the mouth roof. It is slightly pulled down near the quality of the close-mid vowel. When it came to the sound [I], some of the subjects found it problematic. They did not use and posit their tongue properly for producing t the sound [I]. As the result, the sound [I] is changed with other sounds. The following table shows the change of the sound [I] performed by the research subject.

Table 6. Problem with the Sound [I]

\begin{tabular}{|c|c|c|c|}
\hline Position & Word & $\begin{array}{l}\text { The } \\
\text { pronunciation }\end{array}$ & $\begin{array}{c}\text { correct The subject } \\
\text { pronunciation }\end{array}$ \\
\hline Initian & Examine & /Ig'zæmin/ & / sæmIn/ \\
\hline Medial & $\begin{array}{l}\text { Perfect } \\
\text { Preferred } \\
\text { Examine } \\
\text { This }\end{array}$ & $\begin{array}{l}\text { /'pə:(r)fikt/ } \\
\text { /pri' fə:(r)d/ } \\
\text { /ıg'zæmin// } \\
\text { /ðIs/ }\end{array}$ & $\begin{array}{l}/ \mathrm{p} \text { rf kt/ } \\
/ \mathrm{pr} \mathrm{f} \mathrm{rd} / \\
/ \mathrm{Ig} \text { sæmin/ } \\
/ \text { /is/ }\end{array}$ \\
\hline
\end{tabular}

The subjects of the research encountered two problems with producing the sound [I]. First, they were able to produce this sound in the close front area but they did not slightly pulled down their tongues. When this happened, the vowel sound [i] was produced instead of [I] since the vowel sound [i] is higher than the sound [I]. This means that the sound [I] was substituted with the sound [i]. This substitution occurred, for example, in the words ,this /ðIs/ and „examine ${ }^{e e} / \mathrm{Ig}$ 'zæmIn/, the medial [I] sound was substituted by the research subjects with the sound [i] which made them pronounced/ðis/ and /Ig'zæmin/.

Second, the sound $[\mathrm{I}]$ was produced in the front tongue but the tongue was not raised sufficiently that they failed to produce it as a close vowel. The tongue was just raised as the degree of mid-open vowel and it brought about dropping jaw. Then, the vowel sound [ ] was eventually produced instead of [I]. The substitution of the sound [I] with the sound $[\varepsilon]$ happened in two position; initial and medial. The initial substitution can be seen from the word „examine $\mathrm{Ig}^{\mathrm{ee}} \mathrm{zæmIn/}$ which was pronounced / $\mathrm{gg}^{\prime} \mathrm{zæmIn/.} \mathrm{This} \mathrm{means} \mathrm{that} \mathrm{the} \mathrm{initial}$ [I] sound was substituted with the sound [ $\varepsilon]$. The medial substitution can be seen from the

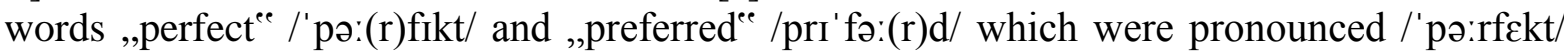
and /pre' fə:rd/. This means that the medial [I] sound was substituted with the sound $[\varepsilon]$. 


\section{b). The Sound [ ]}

The sound [ ] is an open central vowel. Producing the sound [ ] involves the central part of the tongue. However, the sound / / is not a fully open vowel. The central part of the tongue is a little bit raised near the area of the quality of the open-mid vowel sound. The following table show the sound / / caught to be incorrectly produced by the subjects during the research.

Table 7. Problem with the Sound [ ]

\begin{tabular}{llll}
\hline Position & Word & $\begin{array}{l}\text { The correct } \\
\text { pronunciation }\end{array}$ & The subject pronunciation \\
\hline Medial & Multiple public & /'m $\Lambda$ ltipl/ & /'maltipl/ \\
& construct & /'p $\Lambda$ blik/ & /'pablik/ \\
& & $/ \mathrm{k} \mathrm{n} \mathrm{str} \mathrm{kt/}$ & /k n strakt/
\end{tabular}

When producing the sound [ ], some of the subjects of the research underwent one kind of error. The sound [ ] was made fully open by the subjects. The subjects dropped the central part of their tongues in the very low position while actually the sound [ ] needs the tongue to be slightly raised near the area of the quality of the open-mid vowel sound. They eventually substituted the sound [ ] with the sound [a]. This error occurred in the medial position and it occurred in the words ,,multiple $/ \mathrm{m} \mathrm{ltipl} /$, ,,publice /'p blik/ and ,,constructe $/ \mathrm{k} \mathrm{n} \mathrm{str} \mathrm{kt/.}$ The substitution of the sound [ ] with the sound [a] made them pronounced / malt Ipl/, / pablik/ and /k n strakt/.

\section{c). The Sound [ ]}

The sound [ ] is a long mid-central vowel. This vowel sound is, thus, produced a little longer than short vowels. The production of the sound [ ] makes use of the central part of the tongue. The central part of the tongue is raised in halfway between open and close area of vowel sound quality. More specifically, the central part of the tongue position is a little bit pulled down near the area of open-mid vowel sound quality. The shape of the lips when producing the sound [ ] is neutral. The following table shows the altered sound [ ] performed by the subjects during the research.

Table 8. Problem with the Sound [ ]

\begin{tabular}{llll}
\hline Position & Word & $\begin{array}{l}\text { The correct } \\
\text { pronunciation }\end{array}$ & The subject pronunciation \\
\hline Medial & $\begin{array}{l}\text { Heard word } \\
\text { world }\end{array}$ & $\begin{array}{l}/ \mathrm{h}(\mathrm{r}) \mathrm{d} / \\
/ \mathrm{w}(\mathrm{r}) \mathrm{d} /\end{array}$ & $/ \mathrm{hi} \mathrm{rd} /$ \\
& $/ \mathrm{w} \mathrm{rd} /$
\end{tabular}

In some cases, the subject of the research did not succeed in producing the sound [ ] in the correct way. The sound [ ] was incorrectly pronounced in two different sounds. First, the sound [ ] was diphthongized and shortened by the subject. The subject inserted the long vowel [i ] before the sound [ ]. Then, the long [ ] was shortened. Finally, the sound [ ] was diphthongized to be the diphthong [i ]. This was occurred in the word heard $/ \mathrm{h}$ (r)d/. They subject pronounced it /hi $\mathrm{rd} /$ that means that sound [ ] was changed into the sound [i ]. Next, instead of raising the central of the tongue to produce the sound [ ], the subject raised the back part of the tongue. This shows the improper way of producing the sound [ ] altered it to be the long [ ]. This substitution occurred in the words ,word / w (r)d/ and "world" / w (r)ld/. They substituted the sound [ ] with [ ] so that they were pronounced / w rd/ and / $\mathrm{w} \mathrm{rld} /$.

\section{d). The Diphthong [aI]}

The diphthong [ar] is a closing diphthong. It starts with an open vowel and then glides to a close vowel. In this case, it starts with the open central vowel [a] and then moves to the close front vowel [I]. Dealing with the diphthong [ar], some of the research subjects made 
two kinds of pronunciation errors. It was monophthongized into the monophthong $[\mathrm{I}]$ and $[\varepsilon]$. The following table shows the diphthong [aI] substituted with the monophthongs $[\mathrm{I}]$ and $[\varepsilon]$ by the research subjects.

Table 9. Problem with the Sound [ar]

\begin{tabular}{|c|c|c|c|}
\hline Position & Word & $\begin{array}{l}\text { The correct } \\
\text { pronunciation }\end{array}$ & $\begin{array}{l}\text { The subject } \\
\text { pronunciation }\end{array}$ \\
\hline Initial & Identify & /aı'dentıfai/ & /I'dentıfai/ \\
\hline Medial & Classified & /'klasıfard/ & /'klasıfed/ \\
\hline
\end{tabular}

The monophthongization of the sound [ar] to the sound [I] only occurred in the initial position. It happened the sound [ar] in the first syllable in the word "identify" /ai'dentifai/. The mophthongization of the sound [aI] to the sound [I] in the first syllable in that word made it pronounced /I'dentıfaI/. The monophthongization of the sound [aI] to the sound $[\varepsilon]$ only occurred in the medial position. It happened in the sound [aI] in the third syllable in the word ,classified"e /'klasifard/. The mophthongization of the sound [ar] to the sound [I] in the third syllable in that word made it pronounced /' klasifed/.

\section{e). The Diphthong [ ]}

The sound [ ] is a closing diphthong. This means that it starts in an open vowel and then moves to a close vowel. This diphthong starts the sound with the vowel [ ] and then it glides to the sound [ ]. In American English, this diphthong usually starts with the vowel [o] and then it moves the vowel [ ]. By the some of the research subject, this diphthong was changed into monophthong or pure vowel. There were three kinds of monophthongization performed by the subject. The diphthong [ ] was monophthongized into the long vowel [ ] and the short [ ], the long vowel [o ] and the long vowel [u ]. The following table shows the diphthong [ ] substituted with the monophthongs [ ], [ ], [o ], and [u ] by the research subjects.

Table 10. Problem with the Sound [iə]

\begin{tabular}{|c|c|c|c|}
\hline Position & Word & The correct pronunciation & $\begin{array}{l}\text { The subject } \\
\text { pronunciation }\end{array}$ \\
\hline Initian & $\begin{array}{l}\text { Own } \\
\text { Over }\end{array}$ & $\begin{array}{ll}/ & \mathrm{n} / \\
/ \mathrm{v}(\mathrm{r}) /\end{array}$ & $\begin{array}{l}/ \mathrm{n} / \\
/ \mathrm{v} \mathrm{r} /\end{array}$ \\
\hline Medial & $\begin{array}{l}\text { Known chose } \\
\text { spoken focus } \\
\text { component }\end{array}$ & 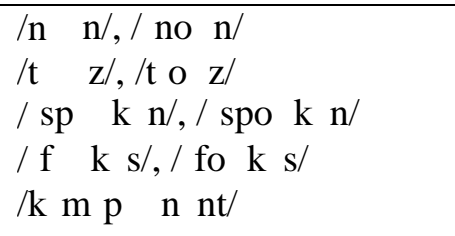 & $\begin{array}{l}\text { /n } \mathrm{n} / \\
/ \mathrm{t} \text { o z/ } \\
\text { / spu k n/ } \\
\text { / f k s/ } \\
\text { /k mp n nt/ }\end{array}$ \\
\hline
\end{tabular}

The monophthongization of the sound [ ] to the long sound [ ] was found in two position; initial and medial. The initial monophthongization occurred to the word ,own $/ \mathrm{n} / \mathrm{h}$ a "over" /' v (r)/. The inital [ ] sound was monophthongized by the research subjects to the long sound [ ] so that they were pronounced / $\mathrm{n} /$ and $/ \mathrm{v} \mathrm{r} /$. The medial monophthongization was found in the word „known ${ }^{e e} / \mathrm{n} n /$. The research subjects monophthongized the medial [ ] sound to the sound [ ] in that word that they pronounced it $/ \mathrm{n} \mathrm{n} /$. The monophthongization of the sound [ ] to the short sound [ ] was found in the medial position. This medial monophthongization was found, for example, in the second syllable of the word „,componente $/ \mathrm{k} \mathrm{m} \mathrm{p.} \mathrm{n} \mathrm{nt/} \mathrm{and} \mathrm{the} \mathrm{first} \mathrm{syllable} \mathrm{of} \mathrm{the} \mathrm{word} \mathrm{,focus}$ / f k s/. The research subjects monophthongized the medial [ ] sound to the sound [ ] in that word that they pronounced them $/ \mathrm{k} \mathrm{mp} \mathrm{n} \mathrm{nt} /$ and / $\mathrm{f} \mathrm{k} \mathrm{s} /$.

The monophthongization of the sound [ ] to the long sound [o ] was found in the medial position. The medial monophthongization occurred to the word ,chose $e^{e e} / \mathrm{t} \quad \mathrm{z} /$. The 
medial [ ] sound was monophthongized by the research subjects to the long sound [o ] so that it was pronounced /t o z/. The monophthongization of the sound [ ] to the long sound $[\mathrm{u}]$ was found in the medial position.

\section{Discussion}

First of all, the pronunciation problem encountered by the research subject was in the form of substituting English consonant sounds with other similar consonant sounds. Phonetically, the consonant sound substitutions happened due to the change of one or more aspects among the three segmental phonetic aspects; voicing, manner and place of articulation. Based on the finding, consonant sounds substitutions occurred to the consonant

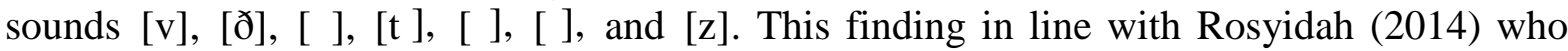
conducted to the students during Language Morning activities. It is important to be noted that her research subjects were those who were not trained and expected to have a good speaking skill. Her research revealed that the students in Language Morning activities also did

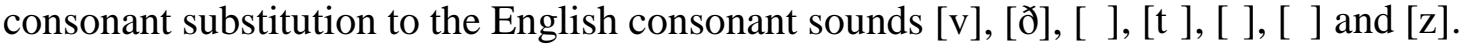

The consonant substitutions which were done by the research subjects in this research can be exemplified as when they had to pronounce / $\mathrm{v}$ ri/ and / $\mathrm{k} \mathrm{klu} \mathrm{(} \mathrm{)n} \mathrm{/}$ which contained the consonant sound $[\mathrm{v}]$ and [ ], they were replaced by the subjects with the consonant sound [f] and [ ] by simply devoicing the sounds [v] and [ ]. As a result, / $\mathrm{v}$ ri/ and $/ \mathrm{k} \mathrm{n} \mathrm{klu} \mathrm{(} \mathrm{)n} \mathrm{/} \mathrm{was} \mathrm{pronounced} \mathrm{/} \mathrm{f} \mathrm{ri} /$ and /k n klu $\mathrm{n} /$. From this example, it can be identified that the research subjects substituted some English consonant sounds with other similar consonant sounds by changing their segmental phonetic aspects. Besides consonants, the research subjects also practiced sound substitutions on the English vowel and diphthong sounds. The vowel sounds were usually substituted with other vowel similar vowel sounds or with the vowel represented in the word spelling. They did vowel substitution to the English vowel sounds [i ], [I], [ ], [ ], [ ], [ ], [ ], [ ], and [ ]. This finding is similar to AndiPallawa's (2013) research which encountered the problem with the English vowel sounds [i ], [I], [ ], [ ], [ ], [ ], [ ], [ ], and [ ].

The vowel substitutions identified in this research can be exemplified as when they had to pronounce "data" / $\mathrm{k} /$ and "public" /'p $\wedge$ blik/ which contained the vowel sounds [ ] and [ ], they were replaced by the subjects with the sound [u] and [a] by means they substituted sounds [ar] and substituted the sound [er]. As a result, /l k/ and / p $\Lambda$ blik/ were pronounced /lu k/ and "public" /'pablik/. From this example, it can be identified that the research subjects substituted some English vowel sounds with other similar sounds.

Furthermore, the vowel sounds were substituted with other vowels which were represented in the spelling. This means that the research subjects often pronounced vowel sounds based on the orthographic writing. This kind of problem occurred the most when they mispronounced the schwa / /. The schwa / / was mostly pronounced as the sound that is usually pronounced based on its orthographic writing. For instance, the word ,isolation ${ }^{\text {ce }}$ and „relevante which should be pronounced /,arsə'leIf(ə)n / and / r l v nt/ were pronounced /,arso'lerfon / and /'reləvant/. It can be seen the sound [ə] in the second syllable of the word ,isolation "was pronounced [0] and the sound [ə] in the final syllable in the word ,relevante was pronounced [a]. This could be motivated by the spelling. The sound [ ] was pronounced [0] as it is spelled with the alphabet , , ${ }^{\mathrm{ee}}$ and the sound [ə] was pronounced [a] as it is spelled with the alphabet , $\mathrm{a}^{\mathrm{ee}}$. In accordance with diphthong, the research subject did diphthong substitution on the English diphthong sounds [aI], [av], [eI], [Iə], and [əv] by monophthongizing them or simply replacing them with other diphthong sounds. This problem was also encountered by Mustikareniees (2013) research subject. They had a problem 
with pronouncing the English diphthong sounds [ar], [av], [er], [Іә], and [əv]. This case was appeared in the research by Ramasari (2017) who found that the participants employed an error in pronouncing the word "data" /deita/ as /data/. It was happened because the students used Indonesian language system in pronouncing English words.

The diphthong substitutions which were done by the research subjects in this research can be exemplified as when they had to pronounce „,classified /'klasifard/ and "main”/meIn/ which contained the diphthong sounds [aI] and [er], they were replaced by the subjects with the sound $[\varepsilon]$ and [aI] by means they monophthongized the diphthong sounds [aI] and substituted the sound [eI]. As a result, /'klasifard/ and /meIn/ were pronounced /'klasifed/ and /main/. From this example, it can be identified that the research subjects substituted and monophthongized some English diphthong sounds. Other than sound substitution, the research subject also committed the consonant sound $[\mathrm{k}],[\mathrm{]},[\mathrm{t}]$ and $[\mathrm{s}]$ deletions and the schwa insertion. However, this pronunciation problem needs to be revealed through the discipline of phonological process rather than phonetic aspects and it is beyond the limitation of this study (Cahya, 2017).

All in all, the segmental pronunciation problems encountered by the research subjects can be summed up as sound substitution. In common, the target sounds are substituted with the similar sounds or the sounds which are usually represented by the orthographic writing.

\section{Conclusion}

The conclusion is stated based on the analysis of the pronunciation problems in terms of segmental phonetic features committed by EFL students of English Departement in their presentations of their thesis proposal,i.e.,

1) During the presentation of their thesis proposal, the research subject under pronunciation problems with a number of consonants, vowels and diphthongs.

2) There were two consonant pronunciation problems encountered by the research subjects. First, they substituted some consonant sounds with other consonants sounding similar to the target sounds. Second, they deleted some consonant sounds when they occurred in consonant clusters.

3) In accordance with consonant sound substitutions, they were in the form of the

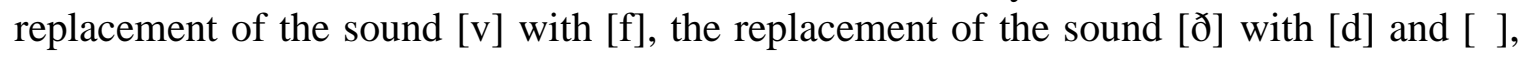
the replacement the sound $[\theta]$ with $[\mathrm{t}]$ and $[\mathrm{s}]$, the replacement of the sound [t $]$ with $[\mathrm{c}]$, the replacement of the sound [ ] with [ ], the replacement of the sound [ ] with [s], and the replacement of the sound $[\mathrm{z}]$ with [s]. In accordance with consonant sound deletion, they deleted the consonant sounds $[\mathrm{k}],[\mathrm{]},[\mathrm{t}]$, and $[\mathrm{s}]$ when they occurred in consonant clusters.

4) There were three vowel pronunciation problems encountered by the research subjects. First, they substituted some vowel sounds with other consonants. Second, they inserted a consonant sound between two consonant sounds. Third, they diphthongized a pure vowel sound.

5) In accordance with vowel sound substitutions, they were in the form of the replacement of the sound [I] with [ ] and [i], replacement of the sound [i ]with[e] and [ ], the replacement of the sound [ ] with [ ], the replacement of the sound [ ] with [u ], the replacement of the sound [ ] with [a], the replacement of the sound [ ] with [ ], the replacement of the sound [ ] with [ ], the replacement of the sound [ ] with [ ], and the replacement of the sound [ ] with [ ], [ ], [a], [ ] and [u]. In accordance with vowel sound insertion, the research subject inserted the sound [ ] between two consonant sounds. In accordance with vowel sound diphthongization, they changed the pure vowel 
[ ] to be [eI], and the pure vowel [ ] to be [i ].

6) There were two diphthong pronunciation problems encountered by the research subjects. First, they monophthongized some diphthong sounds to pure vowel sounds. and Second, substituted diphthong sound other diphthong sounds.

7) In accordance with monophthongization, they monophthongized the sound [aI] into [I] and [ ], the sound [a ] into [ ], the sound [er] into [ ], [i ], and [a], the sound [iə] into [e], and [I], and the sound [ ] into [ ], [ ], [o ], and [u ]. In accordance with diphthong substitutions, they were in the form of the replacement of the sound [eI] with [ar] and the replacement of the sound [iə] with [io].

\section{Suggestion}

After finding the result of this research, the researcher suggests the students of English Department, to seriously learned and concerned with an English pronunciation, in case distinguishing to pronouns vowel and consonant, so that they can assist their speaking skills with an appropriate English pronunciation. Even though the goal of speaking is to deliver meaning without concerning with pronunciation, but they are still expected to have a good pronunciation since they are the students of English Department. Furthermore, the researcher also suggests the lecturers to give feedback and correction the students' mispronunciation during learning activity to get accustomed with a correct pronunciation.

For further research, the researcher suggests the next researchers to investigate pronunciation problems related to suprasegmental phonetic features which include stress, intonation and rhythm since pronunciation involves both segmental and suprasegmental features. Furthermore, the researcher suggests the next researchers to investigate the quality change of sound driven by its position in the phonological environment. This field of study is called phonemic opposition. Finally, as English pronunciation is very problematic even for those who have been studying English for years, the researcher finally suggest the next researchers to find out the factors causing pronunciation problems.

\section{References}

Alimemaj, Z. M. (2014). European Scientific Journal. English Phonological Problem Encountered By Albanian Learners, 10, 159-164.

Andi-Pallawa, B. (2013). International Journal of English Language Education. A Comparative Analysis between English and Indonesian Phonological Systems.1. 103129.

Ary, D., Jacobs, L. C., Sorensen, C., \& Razavieh, A. (2010). Introduction to research in education. New York: Nelson Education, Ltd.

Cahya, N. C. A. (2017). The comparison of pronunciation error in vowel sounds between early adolescence learners and mid adolescence learners in foreign language learning. Journal of English Teaching, Literature, and Applied Linguistics, 1 (1).

Gilakjani, P.H. (2011). A study on the situation of pronunciation instruction in ESL/EFL classrooms journal of studies in education. Journal of Studies in Education, 1, 73-83.

Hornby, A. S. (2005). Oxford Tertiary Learner's Dictionary $7^{\text {th }}$ Edition. New York: Oxford University Press.

International Phonetic Association. (2015). The International Phonetic Alphabet and the IPA Chart. Retrieved March 3, 2020 from https://www.internationalphoneticassociation.org/content/ipa-chart

MacMahon, A. (2002). An Introduction to English Phonology. Edinburgh: Edinburgh University Press. 
Malah, Z., \& Rashid S. M. (2015). International Journal of Languages, Literature and Linguistics. Contrastive Analysis of the Segmental Phonemes of English and Hausa Languages, 2, 106-112.

Miles, M.B., Huberman, A.M. and Saldana, J. (2014). Qualitative Data Analysis: A Methods Sourcebook (3rd Edition). London: Sage Publications.

Mustikareni, D. (2013). Error Analysis on English Diphthongs Pronounced by The Students of SMA Negeri 1 Comal And SMA Negeri 1 Banjarnegara In English Debate on Relax" TV Program of TVRI ( Unpublished thesis), Semarang State University.

Purba, D. P., Bangun, M. N., Pramana, E. P., Sinaga, R. M. J., \& Tarigan, S. N. (2019). An analysis students' vowel in pronunciation. Linguistic, English Education and Art (LEEA) Journal, 3 (1), 180-188.

Ramasari, M. (2017). Students' pronunciation error made in speaking for general communication. Linguistics, English Education and Art (LEAA) Journal, 1 (1), 37-48.

Roach, P. (2009). English Phonetic and Phonology: A Practical Course (4th Edition), New York: Cambridge University Press.

Rosyidah, R. U. (2014). An Analysis of Phonetic Interferences on Students' English Pronunciation in ShobahulLughoh Program of Ma'hadSunanAmpel Al Aly ( Unpublished thesis), English Departement of UNJ.

Sahatsathatsana, S. (2017). Pronunciation problems of Thai students learning English phonetics: A case study at Kalasin University. Journal of Education, Mahasarakham University, 11 (4).

Szynalski, T. P. (n.d.). (2020).. English Vowel Chart [chart]. Retrieved March 3, 2020 fromhttp://www.antimoon.com/how/english-vowel-chart.png

Wikipedia. (2016). International Phonetic Alphabet. Retrieved March 4, 2020 from https://en.wikipedia.org/wiki/International_Phonetic_Alphabet\#English

Yule, G. (2010). The Study of Language. New York: Cambridge University Press. 